\title{
In het diepst van het hart
}

Citation for published version (APA):

Smits, J. F. M. (1993). In het diepst van het hart. Datawyse / Universitaire Pers Maastricht. https://doi.org/10.26481/spe.19930305js

Document status and date:

Published: 05/03/1993

DOI:

10.26481/spe.19930305js

Document Version:

Publisher's PDF, also known as Version of record

\section{Please check the document version of this publication:}

- A submitted manuscript is the version of the article upon submission and before peer-review. There can be important differences between the submitted version and the official published version of record.

People interested in the research are advised to contact the author for the final version of the publication, or visit the DOI to the publisher's website.

- The final author version and the galley proof are versions of the publication after peer review.

- The final published version features the final layout of the paper including the volume, issue and page numbers.

Link to publication

\footnotetext{
General rights rights.

- You may freely distribute the URL identifying the publication in the public portal. please follow below link for the End User Agreement:

www.umlib.nl/taverne-license

Take down policy

If you believe that this document breaches copyright please contact us at:

repository@maastrichtuniversity.nl

providing details and we will investigate your claim.
}

Copyright and moral rights for the publications made accessible in the public portal are retained by the authors and/or other copyright owners and it is a condition of accessing publications that users recognise and abide by the legal requirements associated with these

- Users may download and print one copy of any publication from the public portal for the purpose of private study or research.

- You may not further distribute the material or use it for any profit-making activity or commercial gain

If the publication is distributed under the terms of Article $25 \mathrm{fa}$ of the Dutch Copyright Act, indicated by the "Taverne" license above, 
Unlversiteitsbibllotheek

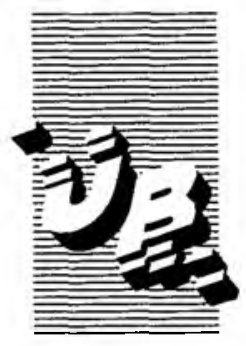

$$
\text { . }
$$

Rijksuniversiteit Limburg Postbus 616

6200 MD Maastricht

Gelieve deze pubiicalie iijaig ie retourneren of (telefonisch) verlenging van de vitleentermijn aan te vragen.

\section{MASDT $199 ?$}
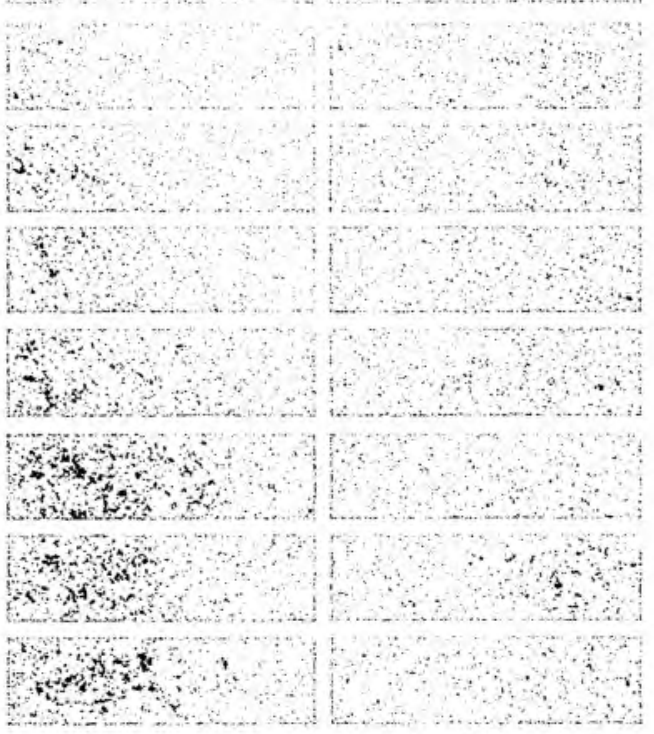


\section{In het diepst van het hart.}

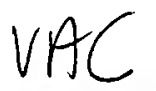

Rede uitgesproken bij de aanvaarding van

het ambt van hoogleraar in de Farmakologie

aan de Rijksuniversiteit Limburg op vrijdag 5 maart 1993

door

DR. J.F.M. SMITS.

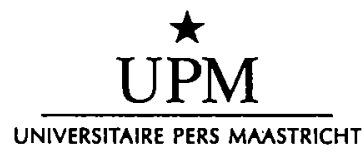


The physician without physiology and chemistry flounders along in an aimless fashion, never able to gain any accurate conception of disease, practicing a sort of popgun pharmacy, hitting now the malady and again the patient, he himself not knowing which.

William Osler (1849-1919)

Aequanimitas, 1900.

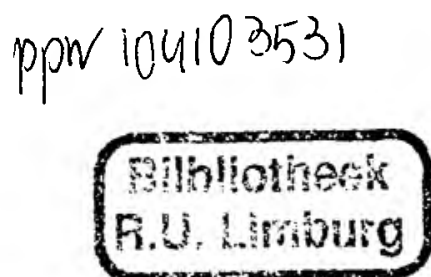

ISBN 9052780722

DATAWYSE | Universitaire Pers Maastricht 
Mijnheer de Rector Magnificus, Leden van het College van Bestuur der Rijksuniversiteit Limburg, Collega's, Familie, Vrienden, Belangstellenden.

Auguren hebben in de klassieke historie een belangrijke plaats ingenomen in de samenleving. $\mathrm{Zij}$ voorzagen in hun levensonderhoud door, uit de vlucht van de vogels, voorspellingen te doen omtrent de toekomst. Zo wordt ook van de hedendaagse augur verwacht dat hij met name de toekomst van het vak waarvoor hij staat in zijn beschouwingen betrekt. Ik wil mijn kijk in de toekomst vooraf laten gaan door een beschouwing van het verleden. Als augur is er tenminste één ding dat je met redelijke zekerheid kunt voorspellen en dat is welke kant de vogels op zullen vliegen. Dat doe je door te kijken waar ze vandaan komen. In die terugblik wil ik voorbeelden gebruiken uit ons denken over het ziektebeeld van het hartfalen en de behandeling ervan. Voor die keuze zijn tenminste 3 redenen aan te geven. Op de eerste plaats is het het onderwerp waarmee ik in het laboratorium dagelijks zelf bezig ben. Dat bezig zijn is overdrachtelijk bedoeld, want mijn fysieke aanwezigheid in het laboratorium is beperkt. Op de tweede plaats, en dat is ook de reden waarom ik er in geïnteresseerd ben, is er het gegeven, de waarneming, dat hartfalen een steeds vaker voorkomend, ernstig ziektebeeld is. En op de derde plaats omdat veranderingen in de farmakologische benadering van het ziektebeeld illustratief kunnen zijn voor de ontwikkelingen in de cardiovasculaire farmakologie.

Maar alvorens dat te doen, wil ik trachten de relatie tussen mijn eigen discipline, de farmakologie, en de overige geneeskundige basisvakken en klinische disciplines te schetsen.

\section{Basisvakken en kliniek als continuüm}

Een plaatselijk hoogleraar chirurgie werd vorige week hier in Maastricht gesignaleerd, terwijl hij zijn dagelijkse mijl aan het rennen was langs de oever van de Maas. Op een zeker moment zag hij enige meters van de kant een drenkeling in het water 
langsdrijven. Zonder ook maar een moment te aarzelen sprong hij in het water en hielp de ongelukkige op de kant. Hij was een echte doordouwer. Na de drenkeling weer op de been geholpen te hebben zette hij dan ook zijn rondje voort. Nauwelijks was hij weer op weg of hij zag een eindje verderop alweer een persoon in het water. Wederom zonder aarzelen sprong hij in de Maas en redde ook deze drenkeling. $U$ begrijpt dat hij daarna weer verder wilde gaan, maar daar zag hij dat er even verderop wel tien mensen in het water langsdreven. Langzaamaan begon de paniek toch toe te slaan en terwijl hij de eerste van die drenkelingen op de kant hees, zag hij een collega hoogleraar in zijn auto langsrijden, een hoogleraar in één van de basiswetenschappen. Amice, riep de chirurg, kom me alstublieft helpen, er drijven hier mensen in het water. De basiswetenschapper reed meteen weg, in de richting van Visé. Wat doe je nu, riep de chirurg vertwijfeld. Kom me alsjeblieft helpen! De basiswetenschapper draaide het raampje van zijn auto open en riep: ik ga kijken wie die mensen in het water gooit!

Gezien mijn sportieve verleden, zullen een aantal mensen, zeker de collega's uit mijn vakgroep, nu geneigd zijn om mij te herkennen in de persoon in die auto. En de eerlijkheid gebiedt me toe te geven dat dat ook gekund had. De farmakologie behoort immers tot de basiswetenschappen. Maar wat ik met dit betoog wilde illustreren is niet zo zeer het verschil in sportieve instelling tussen de chirurg en de farmakoloog, als wel de verschillende wijze waarop beiden geneigd zijn hetzelfde probleem te benaderen. De chirurg staat dan voor de prototypische clinicus, die snel en doortastend handelt. Er doet zich een acuut probleem voor en hij moet de mouwen opstropen, dat staat niet ter discussie. Maar als we er vanuit gaan dat de basiswetenschapper in staat is erachter te komen wat de oorzaak is van het probleem, dan zal dat op termijn een minstens zo belangrijke bijdrage kunnen leveren aan de oplossing van het drenkelingenprobleem als het kordate optreden van de chirurg. Toch zal, op de journalist van het Limburgs Dagblad, de natte chirurg aanzienlijk meer indruk maken dan de gemotoriseerde basisweten- 
schapper. Bij die manier van werken is namelijk meteen resultaat aantoonbaar, terwijl het zichtbare resultaat van de zoektocht van de basiswetenschapper vaak op zich laat wachten. Maar hij zou niet zonder de basisvakken kunnen werken. Want wat ik nog vergeten was te vertellen, is dat de chirurg aan zijn escapades een dubbele longontsteking overhield en gedurende enige tijd antibiotica gebruikte om daarvan te herstellen.

In de relatie tussen basisvakken en kliniek neemt de farmakologie, mijns inziens, een bijzondere positie in. Ervan uitgaande dat therapeutisch handelen het uiteindelijke doel is van de clinicus, dan moge duidelijk zijn dat de wetenschappelijke discipline die hem daartoe de middelen, de geneesmiddelen, aanreikt voor hem van direct belang is. Anderzijds signaleert de clinicus eventuele gezondheidsproblemen in de populatie en de farmakoloog dient van die signalen uit te gaan bij de keuze van het onderwerp van zijn studies. Het is de taak van de farmakoloog om vergaarde kennis uit zijn eigen discipline, maar ook uit andere disciplines, te bundelen en te vertalen naar een praktische entiteit, naar een farmakon. Daarmee neemt hij een brugfunctie in tussen kliniek en basisvakken. Voor de goede orde wil ik hier opmerken dat wanneer ik de term farmakon of het meervoud farmaka gebruik, ik dat niet in de strikte zin van het woord, namelijk "lichaamsvreemde stof" zal doen. De term kan verwijzen naar iedere lichaamsvreemde of -eigen stof, die enige interactie met het organisme heeft.

\section{Gevolgen en oorzaken}

Mijn wetenschappelijke wortels liggen in het onderzoek naar het ontstaan en de behandeling van hypertensie. Hypertensie is één van de aandoeningen die zich kenmerken door het feit dat ze een sluipend karakter hebben. Er zijn epidemiologische gegevens die er op duiden dat 30-40\% van de westerse bevolking aan hypertensie lijdt ${ }^{1}$. De patiënt merkt er meestal niets van en weet pas dat hij hypertensie heeft op het moment dat de arts dat door meting vaststelt. Toch heeft hij of zij een verhoogd risico op 
ernstige complicaties die zich kunnen voordoen op het niveau van de hersenen, de nieren of het hart en die het gevolg lijken te zijn van de verhoogde mechanische belasting van deze organen of de bloedvaten erin. Een hausse van onderzoek, zowel klinisch als dierexperimenteel heeft er vanaf de jaren zestig tot heden toe geleid dat we de verhoogde bloeddruk in de meeste patiënten op efficiënte wijze kunnen behandelen. Toen eenmaal het risico van de hypertensie was vastgesteld, werden op grote schaal geneesmiddelen gebruikt om de bloeddruk te verlagen. Hoewel ze matig effectief waren in de therapie, veroorzaakten ze op grote schaal vergiftigingsverschijnselen omdat het, naar de huidige begrippen, grove middelen waren. Verfijning van het farmakologisch experimenteel onderzoek heeft er echter toe geleid dat steeds betere en veiliger middelen beschikbaar kwamen.

De oorzaak van hoge bloeddruk hebben we tot op heden niet eenduidig kunnen vaststellen. De meest recente onderzoeken suggereren dat bij hypertensieve patiënten een fout in de genetische code aanwezig is die ervoor zorgt dat er een defect is in het renine-angiotensine systeem. Op dit systeem zal ik later, in verband met hartfalen, nog terugkomen. Maar met enige mate van voldoening kunnen we wel vaststellen dat de farmakologie de tegenwoordige internist in staat heeft gesteld nagenoeg elke patiënt met hypertensie op adequate wijze te behandelen, dat wil zeggen, de bloeddruk te verlagen zonder dat daarbij drastische bijwerkingen optreden.

Op enig moment moet men zich natuurlijk wel afvragen of behandeling wel zinvol is. Aangezien niet de verlaging van de bloeddruk het uiteindelijke doel is, maar de voorkoming van de complicaties, moet de vraag gesteld worden of met behandeling van een grote bevolkingsgroep met antihypertensieve middelen die complicaties ook afnemen. Epidemiologische gegevens duiden erop dat dat zo is; het totale aantal complicaties neemt ontegenzeglijk $\mathrm{af}^{2}$. Maar als we de verdeling van de complicaties bezien, dan blijkt dat met name de hersenbloedingen sterk afgenomen zijn. De hart-problemen blijven achter. En die problemen uiten zich of als het myocard-infarct, de hartaanval, of 
als bovenmatige vergroting van de hartspier, waardoor deze relatief ondervoed raakt. Beide problemen kunnen aanleiding geven en geven in veel gevallen aanleiding tot een situatie van hartfalen.

Ook in de behandeling van het myocard-infarct is grote vooruitgang gemaakt, door ontwikkelingen in de cardiologie en de farmakologie. Niet alleen zijn de cardiologen in staat de diagnose vroeger en nauwkeuriger te stellen maar door technologische vooruitgang, gecombineerd met een beter begrip van de processen die zich in de coronaire bloedvaten afspelen, kunnen tegenwoordig op efficiënte wijze doorbloedingsstoornissen in die vaten worden opgeheven. Daarmee is de acute sterfte aan het hartinfarct sterk afgenomen. Dat blijkt echter een Pyrrusoverwinning. Niet alleen is een hartinfarct slechts een uiting van een aandoening van het hart en is het oplossen van een verstopping in dat verband niet meer dan het behandelen van een symptoom, ook lijkt het er nu op dat een hart waarin zich een litteken bevindt zijn struktuur gaat aanpassen op een uiteindelijk onvoordelige wijze. Het gevolg is ook hier weer het optreden van hartfalen.

Door deze schijnoverwinningen, gecombineerd met de toenemende gemiddelde leeftijd van de bevolking, is het hartfalen nu een van de belangrijkste oorzaken van ziekte en sterfte in het oudere deel van de bevolking. Men zou ironisch kunnen stellen dat het toenemend voorkomen van hartfalen is toe te schrijven aan het succes van de farmakologie. Wat niet wil zeggen dat hartfalen een nieuwe ziekte is.

\section{Modelvorming in de wetenschap}

In het verleden waren de ministeries in Nederland op een andere wijze georganiseerd dan nu. De portefeuille Wetenschap werd beheerd door dezelfde minister die ook de portefeuilles Onderwijs en Kunst beheerde, de minister van OK en W: onderwijs, kunst en wetenschap. Reorganisaties hebben ertoe geleid dat onderwijs en wetenschap nu zijn afgesplitst en kunst is onder- 
gebracht bij cultuur. Dat lijkt en is logisch, immers wetenschappers onderwijzen ook. Maar een indeling bij de beeldende kunst zou even logisch zijn geweest. Er zijn namelijk zekere parallellen tussen de twee.

Een schilder geeft ons met zijn werk in feite zijn visie op een deel van de werkelijkheid. Met wat streken verf construeert hij op zijn heel eigen manier een model van, bijvoorbeeld, een zonsondergang. Die eigen manier bevat tenminste drie componenten: de techniek van de schilder maar ook de emotie en bovenal het intellect wat tot uiting komt in de manier waarop hij waarneemt en de wijze waarop hij de losse verfstreken weet te rangschikken op een manier dat een beeld tot stand komt.

De natuurwetenschap functioneert op een vergelijkbare wijze. Uit waarnemingen en metingen krijgt de wetenschapper een aantal losse fragmenten aangereikt. Afhankelijk van de manier waarop hij die gegevens samenvoegt, ontstaat een beeld, zij het nu een abstract beeld, een verklaringsmodel van de werkelijkheid. Maar op een gegeven moment passen de waarnemingen niet meer in het model en wordt een nieuw model opgesteld dat gewoonlijk niet alleen de nieuwe maar ook de oude waarnemingen verklaart. Die steeds veranderende wetenschappelijke beeldvorming, die te vergelijken is met de opvolging van kunststromingen, leidt, naar we aannemen, tot een steeds beter begrip van de werkelijkheid.

Aan het eind van een warme zomerdag is het onvermijdelijk dat de zon aan de horizon in het water zakt. Dat is natuurlijk niet zo; de zon lijkt alleen maar in het water te zakken. Daar zijn we achter gekomen door eens te gaan kijken wat zich aan die horizon afspeelt. En daarbij hebben we moeten vaststellen dat we een vertekend beeld hadden van de situatie. De zon bleek namelijk om de aarde heen te draaien. Eeuwenlang heeft dat beeld de wereldbevolking gerustgesteld. Toen men echter nog beter keek, bleek niet de zon om de aarde te draaien, maar omgekeerd en niet alleen dat, die zon maakte weer deel uit van een grote groep andere zonnen, de melkweg, die zich ergens in een oneindige ruimte bevindt, het heelal. Zeer verfijnde metho- 
den stelden astronomen in staat een model voor dat heelal te formuleren: de oneindige ruimte breidt zich voortdurend uit. Tenminste tot zeer recent hebben we dat aangenomen, want op dit moment zijn er sterke aanwijzingen uit de astronomie die erop duiden dat het heelal wel degelijk beperkt is in afmeting en zelfs weer gaat krimpen. Het momenteel geldende model voorspelt dat het heelal uiteindelijk zal samenvallen in één zwart gat.

$U$ vraagt zich nu ongetwijfeld af wat dit te maken heeft met farmakologie. Ik zal mij niet te buiten gaan aan de farmakologie van de zonne-crèmes. Maar wat ik ermee wil illustreren is, hoe we, door waar te nemen en verklaringsmodellen te formuleren en te toetsen, steeds beter inzicht krijgen in de processen die we waarnemen. Het proces van de ondergaande zon en daarmee de plaats van de aarde in het heelal, wat naar mijn idee één van de oudste raadsels voor de mensheid moet zijn, zijn we beetje voor beetje aan het ontrafelen. Naarmate onze technologieën zich uitbreiden en beter worden kunnen we betere waarnemingen doen en kunnen we, waar nodig, nieuwe verklaringsmodellen formuleren.

\section{Het beeld van het falende hart.}

De behandeling van een ziektebeeld geschiedt op basis van de inzichten in dat ziektebeeld, met andere woorden, op basis van het op dat moment geldende verklaringsmodel voor die ziekte, dat op zijn beurt weer verklaard wordt uit het model van het normale funktioneren. Door de eeuwen heen zijn deze ideeën omtrent de bloedsomloop, die ten grondslag liggen aan de behandeling van hartfalen, drastisch veranderd ${ }^{3}$.

In de oudheid werden de theoretische en praktische kennis van de geneeskunde gedomineerd door magie, mythologie en rituelen. Het hart en de lever hebben daarin als organen altijd een heilige plaats ingenomen. Daardoor was een kille anatomische en pathofysiologische beschouwing uitgesloten. De eerste beschrijving van het ziektebeeld is te vinden in één van de oudste geschriften over geneeskunde en therapie dat we kennen, de 
papyrus van Ebers die dateert van ongeveer 1500 voor Christus. Daar wordt nochtans een ziekte beschreven als overstroming van het hart; in de Egyptische fysiologie was het hart het centrum van alle vaten, zenuwen en lichaamskanalen. De Egyptenaren namen aan dat de overstroming van het hart samenhing met een overmaat aan speeksel. Waarschijnlijk wordt hier verwezen naar de ernstigste uiting van hartfalen, het longoedeem. Een behandelingsmethode wordt uiteraard niet beschreven, want men interfereert niet met een heilig orgaan.

De Grieken begonnen de aandoening actief te behandelen. Een voorbeeld daarvan is terug te vinden in de beschrijving van de behandeling van Heraclites, een beroemd Grieks filosoof die naar alle waarschijnlijkheid overleden is aan hartfalen. Hij trok zich terug in de bergen om te leven van kruiden en planten en zodoende te genezen. Toen dat zijn toestand niet verbeterde, kwam hij weer uit de bergen en raadpleegde hij de artsen. Deze besloten dat zijn huid moest uitdrogen en hoopten dat warmte hem zou helpen. Daarom werd hij geheel bedekt met koemest. Toen zelfs dat niet hielp, gaf Heraclites de moed op en stierf korte tijd later.

Behalve deze onwelriekende methode, kenden de Grieken nog tenminste 3 therapieën. Hippocrates schreef voor de patiënt rechtop te zetten, stoombaden te geven, te wassen met warm water en een incisie te maken in een intercostale ruimte, dat wil zeggen tussen de ribben. Doel was duidelijk het verwijderen van oedeem uit de borstkas. Daarnaast werd in twee therapieën gebruik gemaakt van wat je geneesmiddelen zou kunnen noemen. De eerste was niet onlogisch, gegeven de uiting van de ziekte. In de bossen rondom de middellandse zee leeft een kever, de cantharide. Deze bevat een giftig alkaloïde, het cantharidine, dat sterk blaartrekkende werking heeft. Door de stof op de huid te brengen ontstonden dus blaren en op die manier raakte de patiënt water kwijt. De cantharide is overigens nog steeds in gebruik, zij het uitsluitend voor zelfmedicatie als afrodisiacum, liefdesdrank, en wel onder de naam Spaanse Vlieg. De laatste therapie bestond tenslotte uit het drinken van thee gemaakt van 
de zee-ajuin of scilla. Hierop zal ik later terugkomen, omdat we veel later hebben kunnen vaststellen dat het in feite een heel moderne therapie was.

Rond het jaar 1000 na Christus verschijnt er een boek dat tot in de zestiende eeuw in de westerse geneeskunde als handboek gold. Het was geschreven door Abu Ali Al-Hussein Ibn Abdallah Ibn Sina, bij ons beter bekend onder de naam Avicenna. Deze arabische arts die in Sevilla leefde schreef zijn leer op rijm in 1326 verzen met de bedoeling dat zijn leerlingen op die manier de basis van de geneeskunst eenvoudiger van buiten konden leren. Dit boek heeft meer dan zes eeuwen gegolden als het standaardleerboek voor het medisch onderricht, via een methode die wij hier in Maastricht zo goed kennen, het PGO: Poëtisch Geneeskunde Onderwijs. Avicenna's therapieën waren weer primair gericht op datgene wat hij waarnam, het teveel aan water. Ze bestonden uit aderlatingen, vochtafdrijvende planten als selderij en meloen, braakmiddelen en laxantia.

Tot de zeventiende eeuw verandert er niet veel in het inzicht van het ziektebeeld. In de middeleeuwen was de enige remedie die serieus overwogen werd het houden van een bedevaart. Het plaatsje St-Quentin in Frankrijk was in dit verband een belangrijk centrum. Het succespercentage hiervan is nooit gedocumenteerd en een verklaring voor een eventueel succes kan deze farmako$\operatorname{loog} U$ niet verschaffen.

Pas toen in 1628 Harvey de bloedsomloop beschreven had en de functie van de verschillende organen en verbindende bloedvaten duidelijk werd, kon een begrip gaan ontstaan van het ziektebeeld.

Ongeveer 150 jaar later vond er een doorbraak plaats in de behandeling. In 1775 merkte de Engelsman Withering op dat van alle middeltjes tegen waterzucht die in zijn omgeving gebruikt werden er één was dat leek te werken. Het was een kruidenmengseltje dat door een oud vrouwtje, mother Hutton, werd gemaakt en dat bij veel patiënten baat leek te hebben. Withering was, behalve geneesheer, ook een groot botanicus en ging het mengseltje analyseren. Tussen een twintigtal planten vond hij het 
vingerhoedskruid of digitalis en hij veronderstelde dat dit verantwoordelijk was voor de gunstige effecten van de cocktail. In 1785, dus meer dan tweehonderd jaar geleden, publiceerde hij zijn "Account of the foxglove and some of its medical uses" 4 , met als doel, zoals hij dat zelf aangaf, te onderwijzen in het gebruik van dit kruid. Het bleek namelijk een zeer nauwe therapeutische breedte te hebben, dat wil zeggen dat het verschil tussen een werkzame en dodelijke dosis klein is. Voor de goede orde, Withering begreep de werking van de stof niet. Pas enige jaren geleden, toen onze inzichten in het ziektebeeld en meer specifiek in de werking van het hart waren toegenomen, hebben we kunnen achterhalen hoe de stof werkt, een stof die overigens nog steeds gebruikt wordt in de therapie. Een stof ook, die chemisch zeer sterk verwant is aan een andere stof, het scillareen, dat voorkomt in de door de Grieken al gebruikte zee-ajuin.

\section{De farmakoloog als modelbouwer}

Wanneer we de ontwikkeling van de farmakologie zien als opeenvolging van verklaringsmodellen, is er sprake van een steeds verdergaand abstractie-niveau. De eerste waarnemingen die werden gedaan, waren aan het totale organisme: er was een symptoom van een aandoening bij een individu, bijvoorbeeld een ophoping van water in het lichaam, en behandeling ging wel of niet gepaard met het verdwijnen van dat symptoom. Systematiek ging niet verder dan een systematiek op basis van deze waarnemingen. Voor de goede orde zij vermeld dat we dan spreken over het eind van de vorige eeuw. In het kader van hartfalen, de rode draad die ik wilde aanhouden, werd zo bijvoorbeeld vergelijkend onderzoek gedaan aan digitalis en kwikchloride: beide veroorzaken een toename in urineproduktie maar het mechanisme wat aan ten grondslag blijkt te liggen is, zoals we nu weten, totaal verschillend. Hoe primitief deze indeling voor de moderne farmakoloog ook mag zijn, hij gaf wel een beeld van de uitwerking van het middel op het totale systeem. 
Het doel: de organen

Intussen groeide ook het inzicht in de fysiologie van het organisme. Het werd duidelijk dat het lichaam beschikt over allerlei zeer efficiënte terugkoppelingsmechanismen die een eventuele verstoring door een farmakon teniet kunnen doen. Al snel wordt het dan moeilijk te beslissen of een effect dat je waarneemt, een direct effect is, of een reflex-effect. Zo zal een stof die bloedvaten verslapt, de bloeddruk doen zakken en als reactie daarop laat het lichaam de hartfrequentie toenemen. Kortom, wanneer de hartfrequentie stijgt, hoeft dat niet noodzakelijk een direct effect van de stof te zijn. Er moest dan ook een abstractie gemaakt worden. Metingen werden niet langer verricht aan een totaal organisme, maar aan een geïsoleerd orgaan, of, later, aan stukjes weefsel uit die organen.

Ook de ideeën over ziekten waren overigens naar datzelfde abstractieniveau teruggebracht. Een sleutelvraag in de fysiologie van het hart- vaatstelsel werd al snel, wat de bepalende factor was in de contractie-kracht van het hart. In 1912 presenteerde Starling in dit verband zijn "Linnacre Lecture on the Law of the Heart" ${ }^{\prime \prime}$, waarin hij liet zien dat de contractiekracht afhangt van de mate van vulling van het hart: hoe groter die vulling, des te groter de contractiekracht. Dit fenomeen was voor de skeletspier allang bekend: wanneer een spier enigszins voorgerekt is, dan kan er meer kracht mee opgewekt worden dan wanneer de spier geheel ontspannen is. Er werd vanaf dan aangenomen, dat de waterzucht zoals die optreedt bij een afgenomen contractiekracht van het hart, een verdedigingsreactie van het lichaam vormt. Door de vulling van de bloedvaten te vergroten trekt het van zichzelf verzwakte hart krachtiger samen en genereert op die manier wat extra kracht. Maar als je een spier teveel voorrekt, dan neemt de kracht weer af. Datzelfde speelde zich nu ook op het niveau van het hart af: teveel voorrek, of teveel vastgehouden water, leidde tot verminderde contractie, en dus verder hartfalen. Waterzucht, in de vorm waarover ik hier spreek, was voortaan geaccepteerd als een aandoening van de hartspier. 
De eerder genoemde toename in urineproduktie van kwikchloride en digitalis kon nu functioneel gescheiden worden. Kwikchloride had geen effect op de contractie van het hart maar werkte ergens in de nier. In 1940 werd aangetoond dat digitalis daarentegen de contractiekracht van het hart verhoogt en de hypothese, die overigens nog heden geldt, was dat de urineproduktie na toediening van digitalis stijgt doordat de bloed toevoer naar de nier verbetert. Niet langer was een indeling op basis van een integraal effect op het organisme nodig; een hele stap vooruit.

\section{Het doel: de celmembraan}

Eveneens aan het begin van deze eeuw begon het idee post te vatten dat de werking van een stof op het organisme of orgaan tot stand komt door interactie van de stof met bepaalde specifieke strukturen die in de celmembranen liggen, de zogenaamde receptoren. Als dat zo is, dan ligt het voor de hand te veronderstellen dat chemische strukturen die op elkaar lijken, hun werking zullen hebben via dezelfde receptoren. Een verdere indeling van farmaka op basis van hun chemie volgde, mede mogelijk gemaakt door ontwikkelingen in de chemie die nu voorspellingen kon doen omtrent chemische strukturen. Alweer werd het model verfijnd. Het leven van de farmakoloog werd aanzienlijk vereenvoudigd. En al snel liep hij door het laboratorium, etiketjes plakkend op al zijn potjes chemicaliën.

Die realisatie dat er specifieke receptoren zouden zijn voor farmaka, had overigens vergaande consequenties voor het denken en experimenteren van de farmakoloog. Met het simpele preparaat van het geïsoleerde orgaan of stukje weefsel konden kwantitatieve metingen gedaan worden naar het verband tussen de concentratie of dosis van een stof en het effect ervan, de zogenaamde dosis-werkingsrelatie. Er werden wiskundige modellen ontwikkeld en getoetst om die relatie te beschrijven. Daarbij werd gevonden dat stoffen, als ze op dezelfde receptor inwerken, tot 3 categorieën kunnen behoren. Als ze het effect van de stof die er van nature op werkt nabootsen, zijn het 
agonisten. Als een stof het effect van een agonist tegenwerkt, wordt hij een antagonist genoemd. En als het effect weliswaar lijkt op dat van de natuurlijke agonist, maar kleiner is, dan noemen we de stof een partiële agonist. Dat hield logischerwijs in, dat er blijkbaar twee eigenschappen van stoffen van belang zijn, die los staan van elkaar. De eerste eigenschap bepaalt of een stof een interactie met de receptor kan aangaan, de tweede of hij alleen de interactie kan aangaan of nog iets extra kan doen, namelijk een effect veroorzaken. Het wiskundige model maakte het denken in kwantitatieve termen mogelijk. Farmaka werden van stoffen met een bepaald effect, gereduceerd tot combinaties van twee getallen en er werden nieuwe etiketjes over de oude geplakt. Gelukkig beschikte het lichaam volgens de heersende ideeën van die tijd, ik spreek nu over de jaren zestig, slechts over een beperkt aantal soorten receptoren. Die receptor was overigens een volkomen theoretisch concept. Tijdens mijn allereerste college farmakologie sprak collega professor Ariëns nog over een receptor als een ongetwijfeld beeldschone vrouw in een heel ver land. Je kon er brieven naar sturen, en de prachtigste antwoorden krijgen; maar je zou haar nooit te zien krijgen.

Het doel: de binding

Terug naar het laboratorium, waar inmiddels op het gebied van de receptor-farmakologie een nieuwe technologische doorbraak was bereikt. Het bleek namelijk mogelijk om receptoren te bestuderen zonder naar de effecten te hoeven kijken. De voortvarende farmakoloog wachtte niet eens meer op de prachtige antwoorden alvorens de volgende brief te sturen. Voortaan was het voldoende om weefsel te isoleren, de membranen eruit te vissen en te meten of een stof binding vertoonde aan die membranen. Met die technologie bleek het niet alleen mogelijk om farmaka te karakteriseren, maar ook de omgekeerde weg kon bewandeld worden. In ieder onderdeel van elk weefsel werden de fel-begeerde receptoren gezocht. Dit werk verklaarde weliswaar een aantal van de tegenstrijdigheden die uit eerdere experimenten naar voren waren gekomen, maar riep, zoals ieder goed 
experiment ook weer een aantal nieuwe vragen op. Er waren en zijn nog steeds farmaka die niet van onze receptoren gehoord hebben en zich dan ook niet daaraan conformeren. Met andere woorden, er zullen nog wel onbekende receptoren zijn.

Ontwikkelingen in de moleculaire biologie zorgden hier voor een verdere doorbraak. De moleculaire biologie bestudeert onder andere de processen die zich in en rond het genetisch materiaal afspelen. Met technieken die in die discipline zijn ontwikkeld is het mogelijk gebleken om genetisch materiaal te isoleren en al dan niet te karakteriseren als materiaal dat de code bevat voor een receptor. En als je het geheim van de code kent, dan kun je daaruit de chemische struktuur van de receptor afleiden. Toepassing van die technieken heeft ertoe geleid dat bijvoorbeeld de groep van adrenerge receptoren die ooit uit twee sub-typen bestond, nu uit tenminste 11 sub-typen blijkt te bestaan. Voorzichtigheidshalve moet hierbij de datum van heden (1 februari) in het oog gehouden worden; het is niet uit te sluiten dat er tussen het moment van drukken en uitspreken van deze rede een vermeerdering heeft plaatsgevonden. Deze ontwikkeling, hoe indrukwekkend ook, heeft een conceptueel nadeel. De receptor is nu gereduceerd tot het produkt van een stukje DNA. In de beeldspraak van professor Ariëns is het alsof de vrouw opeens voor je neus staat. En voor je het weet woon je ermee samen. Alleen blijkt dat ze niet in staat is ook maar een woord met je te wisselen. De briefwisseling is blijkbaar via een tolk verlopen. Niet alleen vervreemd je op deze manier van de vrouw die je aanbeden hebt, maar in haar kielzog zijn een aantal verre neven en nichten meegekomen met wie je nog nooit een brief gewisseld hebt en die vooralsnog ook hun mond niet opendoen of open kunnen doen, tenminste niet om te spreken.

Het doel: het inwendige van de cel

Ondertussen was uit experimenten gebleken dat de relatie die Starling had laten zien tussen vulling van het hart en pompkracht, niet zomaar een gegeven was dat door die spiermassa werd bepaald. Die relatie was te beïnvloeden met endogene 
farmaka zoals het adrenaline. Gewapend met de kennis van receptoren en dit gegeven kon de farmakoloog de pompkracht van het hart rationeler aanpakken dan voorheen. Toch bleek al snel een probleem: hoewel we met agonisten voor beta-adrenerge receptoren heel wel in staat zijn om in een geïsoleerd hart een versterking van de pompkracht te verkrijgen, bleek het effect in het totale organisme slechts van zeer korte duur. De receptoren bleken geen statisch gegeven, maar dynamisch, als je ze te lang prikkelt verdwijnen ze.

Gelukkig voor de patiënt met hartfalen kwamen er vanuit de biochemie aanwijzingen omtrent de identiteit van de tolk van de receptor, omtrent datgene wat ertoe leidt dat de interactie tussen twee moleculen, een farmakon en een receptor, aanleiding geeft tot iets relatief groots als bijvoorbeeld het samentrekken van die cel. Het is te vergelijken met twee kleine goudvisjes die elkaar in een enorme vijver ontmoeten; hun paringsdaad doet de vijver overstromen. In de cel wordt dit effect verkregen via een cascade van chemische reacties waarbij slechts een paar moleculen een sleutelrol lijken te spelen. Het organisme beschikt, naar we nu denken, slechts over een beperkt aantal van die cascades, die gedeeld worden tussen verschillende types receptoren. De farmakoloog was natuurlijk zeer geboeid door die ontdekking en kon hiermee het leven aanzienlijk vereenvoudigen. Effecten kun je terugvertalen naar relatief eenvoudige chemische reacties en je zou dus ook rechtstreeks op die reacties kunnen ingrijpen, zonder die wispelturige receptoren daartussenin. Inmiddels werd ook hartfalen begrepen als een chemisch probleem. De vertaling van receptor-bezetting naar effect verloopt, volgens dat model, niet optimaal. Er hapert iets in de cascade. Het farmakologische gevolg was de ontwikkeling van zeer specifieke stoffen die ervoor zorgen dat de stof die in de cel de koppeling tussen beta-adrenerge receptor en contractiele mechanismen verzorgt minder snel wordt afgebroken. Die afbraak wordt verzorgd door een enzym en door daarmee te gaan interfereren was het therapeutisch doel nu van de celmembraan verplaatst naar de ruimte in de cel. Wederom een verdere abstractie. De 
ziekte en de behandeling ervan waren gereduceerd tot een paar simpele chemische reacties.

In het laboratorium bleken deze stoffen allerlei mooie effecten te hebben. Het hart kan extra energie opwekken voor de voortstuwing van bloed. Hoe mooi deze theorie ook lijkt, de praktijk wees anders uit. Nog niet zolang geleden verscheen het rapport van een studie die, onder de veelbelovende naam "Promise" 6 , onomstotelijk aantoonde dat stoffen die dit effect hebben, de fosfodiësterase-remmers de levensduur van de patiënten verkort in plaats van die te verlengen. Voor langdurig gebruik zijn deze stoffen dan ook, bijna per definitie, ongeschikt bevonden.

\section{Ondertussen, in de kamer ernaast}

In mijn betoog tot nu toe, heb ik $U$ geillustreerd dat we er, als farmakologen, in geslaagd zijn de processen die zich in de bloedsomloop en in de cellen die de bloedsomloop samenstellen, naar steeds minder complexe termen te vertalen. De bloedsomloop is niet langer een magische pomp met buizen, maar bestaat in feite uit cellen die in staat zijn sneller of langzamer, krachtiger of minder krachtig samen te trekken, afhankelijk van een aantal chemische reacties die zich erin afspelen. Dat idee is zonder meer juist. Maar gaandeweg hebben we, bijna ongemerkt, een paar vereenvoudigingen gemaakt. Op de eerste plaats hebben we aangenomen dat we de stoffen die een werking op de circulatie hebben, althans de endogene stoffen, redelijk kennen. Daarmee heeft het speuren naar receptoren en koppelingsmechanismen zich beperkt tot de ons bekende stoffen. Wanneer we ons realiseren dat we in de laatste 15 jaren nog tenminste vier hormonen hebben ontdekt met een zeer potente uitwerking op de bloedsomloop, lijkt die aanname op zijn zachtst gezegd voorbarig. Op de tweede plaats hebben we aangenomen dat we de effecten van die stoffen kennen. Natuurlijk zijn er farmaka die de hartfrequentie of de tonus van de bloedvaten kunnen veranderen. Maar door ons in het experimenteren te concentreren op bekende processen, is er wellicht een fenomeen opgetreden wat je ook 
verkrijgt door door een microscoop te kijken. Wanneer je dat doet, ben je in staat om een klein stukje van de wereld in zeer groot detail te zien. Maar tegelijkertijd beperk je het blikveld sterk. Hoe hoger de vergroting, des te beter zie je het detail maar des te minder kans heb je om het grotere verband te herkennen. Dat wordt geillustreerd aan de levensloop van een klein eiwitje, het angiotensine II, dat, naar we nu denken te weten, een zeer belangrijke en onverwachte rol speelt in het proces van hartfalen. En het mooie in die historie is, dat we er niet alleen een breder perspectief van de circulatie mee hebben gekregen, maar tegelijkertijd ook een stap hebben kunnen maken naar nog groter detail, naar het diepst van het hart.

Angiotensine II is een eiwit dat in de eerste ronde etiketten plakken een stof bleek te zijn die zeer potent bloedvaten laat samentrekken en daardoor de bloeddruk verhoogt. Jarenlang vertelden we in colleges dat het de krachtigste stof was die we in dat verband kenden. Door nog eens wat beter te kijken, bleek dat de stof nog een aantal andere effecten had. Het meest in het oog springend was een effect op de nier, dat ertoe leidt dat er water en zout wordt vastgehouden. Die effecten, tezamen met de waarneming dat de spiegels in het bloed van patiënten met hartfalen verhoogd zijn, maakten dat eiwit een interessant doel voor farmakologische therapie. Er kwam een nieuwe groep geneesmiddelen beschikbaar, die de vorming van het eiwit konden remmen. Al snel bleken deze middelen een daverend succes in de behandeling van zowel hoge bloeddruk als hartfalen. De stoffen bleken, beter dan welk ander bekend geneesmiddel, in staat om de gezondheidstoestand en de levensverwachting van patiënten met hartfalen te verbeteren ${ }^{7}$. Die waarneming ging gepaard met de waarneming dat de massa van de hartspier afnam en ook dat de linkerkamer van het hart van vorm veranderde. Die combinatie van waarnemingen heeft onderzoek naar het proces van harthypertrofie, vergroting van het hart, aangewakkerd. Op zich hoeft hypertrofie niet ongezond te zijn. Duursporters bijvoorbeeld vertonen ook harthypertrofie. Het doel van de hypertrofie, zo we ons al mogen afvragen wat het doel is 
van een dergelijke aanpassing, is het aanmaken van meer contractiele elementen om op die manier de steeds weer gevraagde extra prestatie te kunnen leveren. Op den duur is het voordeliger om, als er lang iets extra's wordt gevraagd, de struktuur aan te passen. Als je even sneller wilt gaan, kun je natuurlijk iets harder trappen op je fiets. Maar als je langdurig sneller wilt gaan, kun je beter een auto kopen.

Wanneer je dit proces bij hartfalen nader bestudeert, dan blijkt het hart een samenstelling aan te nemen die we kennen uit de foetus, de ongeboren mens ${ }^{8}$. Het hart in de foetus is niet erg prestatiegericht en hoeft dat ook niet te zijn. De bloedsomloop heeft een totaal andere struktuur en de hoeveelheid arbeid die verricht moet worden is een stuk minder. Het is ironisch dat een ziekte die vooral het oudere deel van de bevolking treft, gepaard lijkt te gaan met een drastische, ongewenste verjonging van het hart.

Remmers van het renine angiotensine systeem interfereren met deze processen. Zo wordt de produktie van bindweefsel teruggebracht naar normale waarden. Ook worden er weer volwassen eiwitten geproduceerd. Jammer genoeg lijkt ook de groei van nieuwe vaten geremd te worden. Maar het totale beeld is er één van een hart dat terugkeert naar zijn normale, volwassen toestand. En dat gaat, zoals al eerder opgemerkt, gepaard met verbetering van de toestand en met name ook verlenging van het leven in de patiënt. Al met al wordt angiotensine II nu begrepen als een stof die nauw betrokken is bij de regulatie van groei. Dat is een effect dat we nooit hadden waargenomen en ook niet konden waarnemen in studies met geïsoleerde bloedvaten of receptor-studies. Het kon alleen gezien worden in het totale systeem, door te observeren op het minst vergaande abstractie-niveau.

\section{Een expanderend heelal of een zwart gat?}

Beschouwingen van de historie kunnen, behalve een anekdotische waarde, ook een leerwaarde hebben. Wat ik gepoogd heb 
te schetsen, is dat de farmakoloog, in zijn zoektocht naar therapeutische aanknopingspunten, voortdurend de aandacht verplaatst naar kleinere details, steeds de microscoop instelt op een hogere vergroting. Dat is een natuurlijk proces. Voortschrijdende inzichten in de details van het functioneren van het normale en zieke organisme nodigen daartoe uit. Het model is bijgesteld. Veel aandoeningen, niet alleen het hartfalen, worden nu verklaard op basis van veranderingen van structuren en dat vraagt om studie van de processen die erbij betrokken zijn. De farmakologie van de $21^{\text {ste }}$ eeuw is er één die zich moet bezighouden met onderzoek naar methoden gericht op het corrigeren van ontsporingen op het niveau van de weefsels. In dierexperimenten is men al in staat om, door in het erfelijk materiaal de code voor een bepaald eiwit, één van de zogenaamde protooncogenen, te blokkeren, de wildgroei van cellen in de bloedvatwand na ballon-dilatatie, het dotteren, specifiek te remmen. Dit proces kan worden geremd, door de stoffen, die de specifieke code in het erfelijke materiaal blokkeren, lokaal toe te dienen 9 .

Maar betekent dat nu dat we de farmakologische laboratoria zoals we die de laatste jaren hebben ontwikkeld en waarin geïsoleerde cellen, weefsels, organen, proefdieren en proefpersonen bestudeerd worden wel kunnen sluiten? Dat zou naar mijn idee een historische blunder zijn, wat ik gepoogd heb te illustreren aan de levensloop van het angiotensine $\mathrm{II}^{10}$. We zullen voortdurend de vertaalslag naar het totale organisme moeten blijven maken. Op het ogenblik dat we ons uitsluitend concentreren op het detail, op het moment dat we van een kunstje een kunstvorm gaan maken, zijn we net te ver gegaan. We kunnen natuurlijk wel gerust een stuk aan ons laboratorium aanbouwen. De farmakologie moet zich nieuwe inzichten eigen maken om haar heelal uit te breiden. Maar waar de studie van de interacties van moleculen een doel is, is het gevaar van het ontstaan van

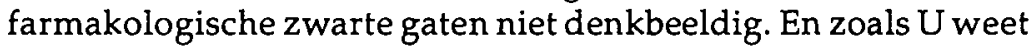
slurpen zwarte gaten alle vormen van energie op, om er nimmer meer iets uit af te staan. 


\section{Dankwoord}

Ik kom nu toe aan het diepst van mijn hart, aan wat ik persoonlijk het leukste, het hachelijkste maar misschien ook wel het belangrijkste deel van mijn rede vind, het spreken van enige woorden van dank. Dank aan allen die elk op hun manier hebben bijgedragen tot het feit dat ik deze rede heb mogen uitspreken. Het hachelijke schuilt in het feit dat het zo gemakkelijk is mensen te vergeten. Mocht dat gebeuren, dan bied ik daar bij voorbaat mijn oprechte excuses voor aan. Op de eerste plaats, niet alleen historisch, wil ik mijn ouders danken onder andere om het feit dat ze de nieuwsgierigheid die ik als kind gehad schijn te hebben, niet onderdrukt, maar juist aangewakkerd hebben. Nieuwsgierigheid is denk ik de belangrijkste drijfveer voor een wetenschapper. Ook een woord van dank aan mijn leraar biologie, wijlen mijnheer van Oostrum die mij ervan heeft weten te overtuigen dat de studie van de levende materie zoveel interessanter is dan die van de dode. Waarmee ik mijn collega en goede vriend de patholoog Doctor Mat Daemen niet wil kwetsen. Hij heeft me geleerd dat ook dood materiaal een schat aan informatie bevat. Ontzettend veel dank ben ik verschuldigd aan mijn hoofdvakbegeleider tijdens mijn studie, aan mijn promotor, mijn collega en bovenal mijn vriend Professor Harry Struyker-Boudier, die al deze hoedanigheden in één persoon verenigt. Dat feit maakt naar mijn gevoel een nadere toelichting overbodig. Wie ik ook zeker niet wil vergeten zijn de collega's en ex-collega's van de vakgroep farmakologie, met wie ik sinds ongeveer 16 jaar zo prettig en vruchtbaar heb samengewerkt. In dat verband wil ik ook de namen van professor Tom Coleman, professor Michael Brody en professor Michael Peach noemen die mij in de gelegenheid gesteld hebben in hun laboratoria te werken en te leren en die elk een stempel op mijn eigen laboratoria hebben gedrukt. De Nederlandse Hartstichting heeft mij middels de toekenning van de Dr Dekker-prijs in de gelegenheid gesteld op comfortabele wijze de overstap van het onderzoek van hypertensie naar hartfalen te maken, een overstap die overigens geïnitieerd is op 
basis van veel lange maar bovenal stimulerende discussies met professor John Urquhart. Maar het allerbelangrijkst voor mij is zonder meer de bijdrage van mijn gezin. Doortje, Anke en Tom weten wel waarvoor ik ze bedank. Ik ben ze er in elk geval onzegbaar dankbaar voor.

Daarmee heb ik gezegd, en dank ik $U$ allen voor Uw aandacht. 
Referenties.

1. National Center for Health Statistics. Health United States 1990. Hyattsville, Maryland: Public Health Service; 1991. Wanneer hoge bloeddruk gedefiniëerd wordt als een bloeddruk $>140 / 90 \mathrm{mmHg}$, lijdt $30 \%$ van de vrouwelijke en $40 \%$ van de mannelijke Amerikaanse bevolking aan hypertensie.

2. P.S. Sever. 1985 - The year of the hypertension trials: interpreting the results. Trends in Pharmacological Sciences 7: 134-139, 1986.

3. C. Régnier. Le patient insufficiant cardiaque à travers les ages. Edition Tabloïd Communication, France, 1992. ISBN 2 - 9505194 $3-1$.

4. W. Withering. An account of the foxglove and some of its medical uses. Birmingham: Swinney, 1785.

5. E.H. Starling. The Linnacre Lecture on the Law of the Heart. London: Longmans, Green and Co, 1918.

6. M. Packer en anderen, namens de PROMISE Study Research Group. Effect of oral milrinone on mortality in severe chronic heart failure. The New England Journal of Medicine 325, 1468-1475, 1991.

7. Consensus Trial Study Group. Effects of enalapril on mortality in severe congestive heart failure: Results of the cooperative North Scandinavian Enalapril Survival Study (Consensus). The New England Journal of Medicine 316, 1429-1435, 1987.

8. K.R. Chien, K.U. Knowlton, H. Zhu en S. Chien. Regulation of cardiac gene expression during myocardial growth and hypertrophy: molecular studies of an adaptive physiologic response. The Faseb Journal 5: 3037-3046, 1991.

9. M. Simons, E.R. Edelman, J. DeKeyser, R. Langer en R.D. Rosenberg. Antisense $c-m y b$ oligonucleotides inhibit arterial smooth muscle cell accumulation in vivo. Nature 359: 67-70, 1992.

10. A.M. Katz. Angiotensin II: hemodynamic regulator or growth factor. Journal of molecular and cellular cardiology 22: 739-747, 1990. 